\title{
Chamaecyparis obtusa Wood Oil
}

National Cancer Institute

\section{Source}

National Cancer Institute. Chamaecyparis obtusa Wood Oil. NCI Thesaurus. Code C107284.

The oil extracted from the wood of Chamaecyparis obtusa. Hinoki wood oil has antibacterial properties and is used in perfumes, toothpaste, and hair tonic as well as for aromatherapy. 